\title{
Philosophy in Dialogue with Culture through Hermeneutics
}

\author{
Nelson Udoka Ukwamedua*
}

\section{Abstract}

Man as a product of the society is a bye-product of culture; and man also uses culture as material in the quest to live well and understand the environment and the world around him. This interplay accentuates the correlation between man and culture. Due to the critical role culture plays for man, culture as a dynamic scheme constantly needs redefinition and refinement. This is to ensure and assure the relevance of culture and the sanity of man. This paper undertakes a critical analysis of culture and philosophy and it unearths their implications for social order towards social harmony. Hermeneutics was then suggested and employed as the key to appreciating and properly situating culture using the critical tool of philosophy. This process in dialogue is in view of making man flee from the slavery of a cultural scheme that degrades man status which has the potential of hampering man's wellbeing.

http://dx.doi.org/10.4314/ujah.v13i1.10

\section{Introduction}

Man as a rational being has the ability to discriminate between what belongs to him and what does not. Man deciphers where and how to appreciate and situate himself and relate to the outside world. It is then axiomatic that a foremost medium of classifying man is his way of life and how he reacts to his immediate environment. This way of life and man's interaction with the environment is what the term culture embodies. Evidently when men congregate, the major mark of their uniqueness is perceived in the way they react to things and this underscores the role culture plays. Substantiating this, Mondin observes that "in the past, men based themselves on reason, 
freedom, and language to distinguish man from the other beings. Today it is understood that one aspect, one dimension...to man is culture. This aspect characterizes man and distinguishes him from animals no clearly than reason, freedom and language".

One of the major characters of culture is change; this should come as a result of adoption, interpretation (hermeneutics) and adaptation through dialogue. Dialogue is the umpire and it achieves this via the expertise of philosophy. This endeavour is premised on the fact that "the incontrovertible historical fact of cultural pluralism constitutes the historical background for the exercise of philosophical thinking...philosophy is culturally based..."2. This paper esteems the tremendous role of culture in human endeavour. The author then argues for the necessity of the dialogue between culture and philosophy through hermeneutics; in the quest to give culture a distinctive and relatable mark.

\section{Understanding Culture}

A better appreciation of the meaning of culture stems from the etymology of the word, which can be traced back to the Latin cultura, deriving from the word colere, meaning both to 'cultivate' and to 'worship'. It is a compelling fact that the very origin of the word culture contains the wisdom of the people's understanding of culture as the worshipful cultivation of something, particularly the land. Spirkin ${ }^{3}$ further observes that the word 'culture' from the inception connotes good action. And action usually means assimilation of our world in one form or another. Culture can then be seen as a kind of prism, through which everything essential to us is refracted. The common mode of defining culture is that; it is the way of life of people. Mondin ${ }^{4}$ exposed it in three senses; in its elitarian sense, it signifies a great quantity of knowledge; in its pedagogical sense, it connotes education, formation and cultivation of man towards maturity; in its anthropological 
sense, culture typifies the customs, values and schemes that distinguish a group of people from the others. There is also a distinction between the scientific culture (mathematics, physics, astronomy, medicine) and the humanistic culture (philosophy, art, history, anthropology, literature). A demarcation also exists between material (the base structure of the society, and also economic), and ideological culture (concerned with law, history, religion, politics, arts). Other distinctions are; between preliterate and literate culture, traditional and urban culture, peasant and citizens culture etc.

One need not reason for long to appreciate the conviction that the concept of culture is an integral and an allembracing concept which includes various phenomena and methods of administering the state. Culture defines everything that man does, and how he does it, in the process of selffulfillment. Culture is the method of the self-realization of the individual and society, and the measure of the development of both. Various fields in knowledge- ethnography, archeology, history, literary criticism and so on - all study the various spheres of culture. Such forms of the spiritual life of society as science, literature and art are facts of culture. They organize and ennoble human feelings and serve as the plastic means that connects the reason and the heart in a single whole, thus eliminating the disharmony that often arises between them ${ }^{5}$.

Anthropologically, culture signifies that totality of customs, techniques, and values that distinguishes a social group, a tribe, a people, a nation; it is the mode of living proper to a society. ${ }^{6}$ Culture is characterized by the vital ideals of humankind, of the individual, the social group, the class and society as a whole; the more significant these ideals, the higher the level of culture. Outside culture the individual cannot exist as a human being. As water permeates soil, so culture permeates every pore of social and individual life. When studying one or another culture, we usually think of it as something relatively independent. In reality, culture exists as a 
historically evolved system comprising its objects, its symbolism, traditions, ideals, precepts, value orientations and, finally, its way of thought and life, the integrating force and the living soul of culture. In this sense, culture subsist supraindividually, while at the same time remaining the profoundly personal experience of the individual. Culture is created by mankind, by the nation, the class, the social group and the individual.

However, what we are interested in here is not the numerous spheres in which cultural activity of various peoples, nations, ethnic groups, social groups and individuals have manifested themselves, but the essence of culture, i. e., culture as a philosophical category.

\section{Culture, Social Order and Philosophy}

Culture is the mode of a people's existence that tailors their self-realization and development. This is entangled with the issue of social order because; culture is geared towards the serenity and progress of the extended society. In trying to achieve this form of social order, philosophy is a necessary condition due to its rational and critical quality. Culture concerns our way of life, and philosophy as a critical endeavours is towards the truth of our existence. Social order refers to the social systems and schemes of social relations that define the political, social, economic and social roles, rights and duties of people in a society ${ }^{7}$. Taking into account the primacy of a stable social order to the progress of any society, Adeniran Aluko posits that it is imperative to marshal both intellectual (philosophy) and material resources (culture) towards achieving a stable and sustained social continent and that the essential mark of philosophy is how to redirect culture to sustain social ${ }^{8}$. On this trend Mbiti contends that, "philosophy of one kind or another is behind the thinking and acting of every people and a study of traditional religions brings us into those areas of African life where, through word 
and action, we may be able to discern the philosophy behind"9. The interaction of the triad (philosophy, culture and social order) was captured by Ali Mazrui ${ }^{10}$ when he identifies the functions of culture as it concerns social harmony. Culture plays a fundamental role when it comes to perception and cognition. Verily, the way people see the world spans from their cultural keystone. In this wise, culture serves as a form of social integration and regeneration. In this process, philosophy plays the role of ensuring proper and in-depth understanding, analysis and appreciation of the culture as a tool so that the hope of a social order is properly put in perspectives and not misplaced ab initio

To ensure social concurrence, culture provides the motive for human behaviours and this serves as a contrivance for social change and control. This is decisive especially as it concern inter-relations. Philosophy clarifies and also give reasons for human actions and endeavours hence there are philosophical grounds for our projections. Hence Omoregbe contends that philosophy is a reflection on human experience in search for answers to some fundamental questions. ${ }^{11}$ More still, through evaluation culture assists the society to guarantee social integration and wellbeing. In the quest for harmony in the society, there is need for a moral arbitrator to determine what to approbate and reprobates. This function is exclusive to culture as the custodian of the people system of belief and customs. Philosophy has evaluation as its major tool in the process of analysis and the search for truth and its relationship with culture bestows to the society a germane cultural scheme that fosters social order and cohesion.

An outstanding mode of identification and stratification is culture. It is instructive to state that most squabbles that exist are due to wrong perception of someone's identity and this tends to hamper social order. Philosophy also has a role to play because the foundation of most epistemological systems is borne out of the issue of identity clarification. Starting from 
John Locke through Descartes to the existentialists, identity plays a central role in the sphere and this role of culture will be marred if it does not appreciate the tools of philosophy in this regard. Furthermore, social order is petty if there is inadequate and unreliable communication system; in this wake, culture helps to breach any form of rancor by helping to communicate accordingly what they should do in a given time, place and circumstance. It helps to relay ideas and views of a people to others. It can take the form of language (and this is the tool of philosophy) in passing across the result of its research and findings. For this reason, philosophy helps to interpret and transfer the relevant ideas to those concerned.

From the foregoing, culture, philosophy and social order are the major trappings in the reorganization of the society, sustenance of social order which is towards the wellbeing of man.

\section{The Dialogue between Philosophy and Culture}

The thinking mind of culture is philosophy in that philosophy helps culture to properly appreciate its schemes and work wisely towards assisting the sustenance of man's dignity. Philosophy and culture are congenial; they need each other to remain germane and perennial, this relationship however is both complex and interesting. Culture needs philosophy for clarification and philosophy needs culture as its material for reflections. Man is a situated being, man speaks from within an environment or culture with particular expressions and language; and philosophy is thus embellished by a variety of experiences ${ }^{12}$. Philosophy is culture-bound thus one can speak of Indian Philosophy, African Philosophy, Chinese Philosophy etc, they operate in and from a cultural setting. Complementing this Samuel Oluchi Imbo argues that “.... philosophy always springs however indirectly from the society in which the philosopher grows up..."13, leaning from the above submission, it is pertinent to remark that philosophy as a 
rational and critical enterprise that seeks the knowledge of the truth has to critically analyze culture and its corollary so that the truth is sought. The face of culture bears the imprint of humanity, and anything that is against humanity is not culture but anti-culture. For example, such highly technical sophisticated means of murder and violence as war, torture, and imprisonment, have nothing in common with culture, although they occur in civilized societies. Can the brutalities of despotic regimes be described as a phenomenon of culture? Can the means of mass annihilation be called a material reality of culture? The constant accumulation of cultural values places increasingly complex demands on education and particularly philosophy as a most essential form of the creation of culture.

Anywhere and anytime, philosophy serves as a tool for cultural cleansing; this will be relevant especially in Africa as some aspects of our traditional belief systems are anachronistic and need revision or total extermination. This is because they portend great threats towards the requirement for the achievement of a shrewd contemporary society. A case in point is the status, identity and place of women, servants, slaves (osu) and children in Africa. Some of the treatments meted out to them hamper the spirit of equality and liberalism which is in vogue and is a desideratum in the quest to foster the respect and dignity of human beings. Abiola Irele envisages the corollary of these anomalies and the imperative of an alternative as he reasons that "the resources in ideas, techniques, and in certain respects values offered by our traditional cultures are simply not adequate for our contemporary needs and interests". 14 This calls for a drastic and a pragmatic rejuvenation of our cultural artifacts and an ideal cultural orientation. Philosophy should nip this absurdity of cultures from the bud as it takes a scrupulous look at cultural schemes. Philosophy as a rational enterprise has to critically examine any aspect of culture whether morality, politics, religion, and tradition, it probes into its significance 
and relation to life in general. ${ }^{15}$ Philosophy's input is fundamental in the re-examination of world-views, customs, and beliefs and reinterprets them in the light of reason and modernity. It helps to thoroughly scrutinize and synthesize the theoretical basis for some of the practices in lieu aligning them with the best practices towards ensuring integration, understanding and human dignity. Reiser, understood the input of philosophy in the integrate of ideals and schemes towards a better system when he avers that, 'It is no distortion to urge that the failure of the modern world is the failure of philosophy to live up to its historic role of providing synthesis, wisdom and logical guidance to our increasingly perplexed world 16

J.S. Mbiti observes that Africans are notoriously religious, however this religiosity sometimes appears to be the raison d'être for some obnoxious and banal cultural practices and schemes hence, in the light of a phenomenology of religion together with a conscientious philosophy of religion, philosophy should strive to strike a balance between reason, emotion and sentiments while not obliterating totally the religious affinities/professions of Africans. Also philosophy should in the light of culture change and integration help to expose these cultures to the scientific and technological culture which today guarantee the wellbeing of man. Kwame Gyekye buoys up this point thus; "the material and survival of human society depend on the ability of humans to make at least simple tools and equipment and to develop techniques essential for the production of basic human needs such as food, clothing, shelter and security". 17 (And communication and networking which is in vogue now).

Spiraling the value and potency of culture George Will, a columnist in the Newsweek Magazine, pointed out that the culture of a people; customs, mores, traditions, values, institutionalized ideas - rather than just legal institutions and economic policies, are agents of progress in a society. George Will observes that "the spread of democracy, free markets, 
technology and information is not enough to rescue many nations from the consequences of their cultural deficits..." and he was quick to add that "...such deficits, although not incurable, are intractable"18. Despite this frustrating remark of George Will and the ostensible daunting task, it is rewarding to state that philosophy remains an effectual tool for social reconstruction and reorganization right from the ancient times to the present day, as evident in the constitution of America which owns its structure to John Locke's liberal philosophy ${ }^{19}$. Consequently philosophy should come into dialogue with cultures and see how the social structure can be retooled against all odds. Through the conceptual apparatus of philosophy the system of world-view, the methodology of cognition and the transformation of the world and man himself are organized.

The tree of authentic philosophy remains timeless and universal, but it has its root in culture ${ }^{20}$. It germinates from culture, experience, human will and at times human arbitrariness. As long as everyone belongs to an age or culture, not minding the age or the school of thought of a philosopher, the person is first and foremost a person of culture, a product of the education and belief of the person's society. If a philosophy in a culture sets a higher standard of philosophizing, it is because it set a higher standard of education, belief, knowledge, moral and social values than in some culture. This may also include the propensity for critical examination $^{21}$. This synergy will help to enthrone peace, understanding and stability in the system. Philosophy also extends its role to exposing the basic assumptions that govern the cultures of people so that the people will appreciate it in truth. $^{22}$ Concerning this Appiah affirms that 'society without norms could hardly exist not simply because the concept of society is connected with the idea of a shared norm but because without norms it is difficulty to conceive of any collective action'. ${ }^{23}$ However, the constancy of culture as 
George Will affirmed might expose it abuses that is why philosophy in the spirit of dialogue should map out a vision that will give meaning, direction and guidance to culture. This should be coupled with proper pragmatic and rewarding norms that will duly propel the society positively.

\section{Culture and African Philosophy}

Two of the major current that sustained the great debate of African philosophy which has links with culture is the sage and ethno philosophy propounded by Odera Oruka. The sage philosophy has to do with thoughts of wise men and women within the community; it fluctuates between known maxims and rational thoughts of some given individual within the community $^{24}$. Corroborating Oruka, Ochieng confirms that sage philosophy is the body of basic principles and tenets that underlie and justify the beliefs, customs and practices of a given culture. $^{25}$ This idea spurred the interest of Hountondji ${ }^{26}$ who insisted that sage philosophy and ethno philosophy (both hinged on cultural schemes) are not philosophy because they lacked a literal tradition among others defects and he concludes that at worse they are reactionary and carried out within western categories, and in the end, it falsifies philosophy. Responding to Hountondji, Marcien Towa differs on the issue of literacy as a paradigm for African philosophy but critiques ethno philosophy with this words; "they interrogate rituals, myths, arts, poetry, language, social political and educational institutions, etc, on the pretext that philosophy is incarnated in the life of a people". ${ }^{27}$ In dire situation and polemics about culture and its existence as this, philosophy creeps in with criticality, reason and dialogue as tool to help in further evaluation, interpretation and the rebirth of culture.

In trying to further use philosophy to rescue culture from the abyss of incongruity Imbo prescribes a guarded sifting through the oral literacy texts for consistencies, 
irrelevance, and untruths; and that only text that survive this scrutiny can be relied upon to contribute in making Africa powerful again. $^{28}$ Assenting to Imbo view, Towa then asserts that through this same philosophical cleansing, the traditional realities that impede science are to be abandoned and the values that aid technology cultivated, as it leads to bridge building, and enhances development and integration in the future. $^{29}$ This process of sieving and reconstruction is the contribution of philosophy in dialogue with hermeneutics and this is to ensure cultural convalescence. This precipitated the conclusion of Chiek Anta Diop as he concedes that philosophy is read from various aspects of the cultural life of a people and philosophy is the harbinger of truth reality and understanding. ${ }^{30}$

\section{Hermeneutics: Interfacing Culture and Philosophy}

The affinity that exists between culture and philosophy is made possible through dialogue. Hermeneutics remains the sterilized strap as philosophy proceeds to the table of dialogue. Before philosophy duly situates culture in lieu of dialogue, it has to interpret culture and this is where hermeneutics is inimitable. The term hermeneutics, a latinized version of the Greek hermeneutice, has been part of common language from the beginning of the $17^{\text {th }}$ century. Nevertheless, its history stretches back to ancient philosophy. ${ }^{31}$ The folk etymology places the origin of the word hermeneutics (Greek: hermeneutike) with Hermes, the mythological Greek deity whose role is that of messenger of the gods. Besides being mediator between the gods and humanity, he leads souls to the underworld upon death, is the inventor of language and speech, interpreter, a liar, thief and trickster. These multiple roles make Hermes an ideal representative of hermeneutics, for, as Socrates notes, words have the power to reveal or conceal, thus promoting the message in an ambiguous way. The Greek view of language as consisting of signs that could lead to truth or 
falsehood is the very essence of Hermes, who is said to relish the uneasiness of the messaged. ${ }^{32}$ With the emergence of German romanticism and idealism the status of hermeneutics changed, hermeneutics turned philosophical. It is no longer conceived as a methodological or didactic aid for other disciplines, but turns to the conditions of possibility for symbolic communication as such.

In the mid-1920s, it was triggered by Martin Heidegger's Sein und Zeit and carried on by his student HansGeorg Gadamer. Now hermeneutics is not only about symbolic communication. Its area is even more fundamental; that of human life and existence as such. It is in this form, as an interrogation into the deepest conditions for symbolic interaction and culture in general, that hermeneutics has provided the critical horizon for many of the most intriguing discussions of contemporary philosophy. Martin Heidegger's philosophical hermeneutics shifted the focus from interpretation to existential understanding as a more authentic way of being in the world than simply as a way of knowing ${ }^{33}$. The issue of hermeneutics in modern philosophy dates back to Heidegger and this was later championed and given a snooping style by Paul Ricoeur. That of Heidegger was a way of being (ontology). Informed by his reading of Schleiermacher, Droysen, and Dilthey, Martin Heidegger's Sein und Zeit (1927) completely transformed the discipline of hermeneutics. In Heidegger's view, hermeneutics is not a matter of understanding linguistic communication or a methodological basis for the human sciences. But for Heidegger hermeneutics is ontology; it is about the most fundamental conditions of man's being in the world. Yet Heidegger's turn to ontology is not completely separated from earlier hermeneutic philosophies $^{34}$. This mingling of culture, philosophy and hermeneutics was encapsulated by Okere as he claims that, "...it is only within the context of hermeneutics that African culture can give birth to African philosophy..."35, Okere 
further avows that the failure of an authentic African philosophy in the past was because scholars have neglected the cardinal place of hermeneutics of culture into philosophy. As against the Heideggerian ontology, Ricoeur rather used hermeneutics as a method of understanding and interpretation; a philosophical hermeneutics that addresses the problem of the truth of existence, and this is the aspect that concerns culture and philosophy. Ricoeur contends that element of meaning is common to all hermeneutics. For hermeneutics, whatever is intelligible is accessible to us in and through language and all deployments of language call for interpretation. Accordingly, "there is no self-understanding that is not mediated by signs, symbols, and texts; in the final analysis self-understanding coincides with the interpretation given to these mediating terms" 36

A common structure of this element is double-meaning and this is what Ricoeur calls symbols. It is pertinent and paramount to take cognizance of the fact that most cultural schemes are embedded in symbols so, a philosophical interpretation of cultural symbols both hidden and apparent (in religion, custom, arts, status, poetry etc.) is expedient. ${ }^{37}$ It is also by interpreting the symbols of a culture that one arrives at reflexion (comprehension of signs and symbols) and consequently philosophy. For Ricoeur, there are levels, the phenomenological state (interpret symbols in relation to another towards coherence), hermeneutical state (deals with belief and truth value) and the reflexive stage (thinking from explicated symbol into discourse). ${ }^{38}$ Thus for Paul Ricoeur, one can philosophize from culture or at least from the elements of culture that can be called symbols because the latter is pregnant with meaning and has to be explained and understood with the aid of reason within the confines of philosophy; this in fact underline why philosophy is hermeneutical. For this reason, any question of relation between culture and philosophy is a hermeneutical problem and calls for a fitting 
method so; hermeneutics mediates between philosophy and culture. Instructively, culture as such with its various manifestations is not philosophy. Philosophy arises from culture and the mediation between the two is the process of hermeneutics which has to do with the interpretation of symbols of the culture under study. That is why Okere believes that there are evidences of symbolic elements in African culture. Hence, Ike Odimegwu echoes the fact that Okere subscribes to this view that philosophy must be hermeneutical, yet it must also get its initial impulse and nourishment from the African culture $^{39}$. As an addendum, Oguejiofor avows that this form of production is not automatic i.e., philosophy is not simply a coming together of cultural symbols and the hermeneutical process. It is a creative enterprise, and creativity presupposes the presence of a genius 40 .

This interface between culture, philosophy and hermeneutics was the point of departure of the philosophy of Okonda, ${ }^{41}$ he concurs that we have to retain the lesson of contemporary hermeneutic and extend the sense of a text to include all verbal concatenations and all that offers itself to be read, including tradition. More so, he maintains that there should be a reflexive embrace where contradictions and tensions are analyzed and that, it is the African tradition that ought to assure the hermeneuticity, the philosophicity, and hence the Africanity of a determined practice' that African philosophy should be able to make wise judgement and do away with elements that inhibit its growth and identity. He finally reasoned that culture and historical experience should avail themselves the scrutiny of philosophy so that they can become liberating, creative and germane. ${ }^{42}$. This scrutiny that Okonda envisages is what hermeneutics comes to do and at the end of the exercise a sane culture is bestowed. 


\section{Culture and Man}

It was in his existentialist submissions that Martin Heidegger ${ }^{43}$ postulated that; Dasein is a being in the world and also a being with others. Heidegger used existential phenomenology to demonstrate this and termed it existentialia. This shows that being has a mode of existence which it uses to relate with the world; this underscores the synergy between culture and being. Man therefore is a cultural being because from birth he forms himself and progresses through and within the precincts of society and culture. Man is a product of history and nature but primarily, man is a product of culture. Culture forms part of the constituent element of man's essence. In this sense man is a phenomenon of culture, not only of nature. If we may attempt an analogy, it may be said that culture is the opened, read and understood pages of the 'book of life', pages which when assimilated by the individual become his selfhood ${ }^{44}$. Man is an artifice of culture and remains the greatest effect of culture. Without man culture cannot pride itself because man is its prime receiver. It also helps in the distinction between what man is and what he has, between 'being and having'. Man therefore remains at the centre of all the activities, from culture in dialogue with philosophy through hermeneutics, man takes the central stage.

\section{Concluding Reflections}

Culture remains a crucial concept and aspect in the development of society and progression of man. Hence, it needs proper understanding and constant review so that it remains relevant in its distinctive role. The implication of this is that it has to undergo series of evaluation so that, its tenets will continue to produce positive result and not endanger its species. Philosophy is what makes sure that culture does not go extant or become obnoxious and threatening consequently it need to always put it in perspective for man's good. Substantiating this, Mondin remarks that apart from the 
function of dominion, knowledge and exploitation of nature, the primary and principal objective of culture is man (not just man but his wellbeing and survival), it is man who is cultivated first before anything else. He therefore concludes that culture cannot be anything except humanistic whether as a means or an end while the scientific aspect of culture assist the former. $^{45}$

It is causal to state that this decisive enterprise of philosophy in culture only becomes a reality with hermeneutics. To evaluate culture, it has to be interpreted and then related in dialogue. This is bearing in mind that some of the misunderstanding and misgiving over the years are as a result of misconception and misrepresentation of cultural schemes; that is why there is need for the trio of culture, philosophy and hermeneutics to work accordingly. This is to forestall the ludicrous situation where man who is a product and an agent of culture becomes dim-witted before culture and an infinitesimal article of culture. Forestalling this menace will efface a horrid cultural atmosphere and enthrone a stable, esteemed, and a punctilious cultural scheme for man to relish. This is considering the fact that socialism has brought different ideals and standards of culture that are permeated with a profound and comprehensive humanism, as expressed in the maxim; 'everything for the benefit of man and everything in the name of man'. The freedom of every person is seen as an indispensable condition for the freedom of all. This is the truly humane principle of life and standard of cultural development that permeates the whole world outlook of socialist society.

* Dr. Nelson Udoka Ukwamedua has just completed his $\mathrm{PhD}$ studies in Philosophy from the Department of Philosophy, Nnamdi Azikiwe University, Awka. 
1 Battista Mondin, Philosophical Anthropology, (India: Theological Publications in India, 1985), p. 148.

2 G. Otapkor, A. Isiguzo \& G Ukagba 'The Universe, Cultural worlds and Philosophy' in West African Journal of Philosophical Studies (WAJOPS),(Vol. 4 December, 2001), pp. 49 - 71.

3 Spirkin, A. Dialectical materialism, (Chapter 5, On the Human Being and Being Human), in www.Marxist.org/reference/archive/Spirkin/works/Dialect ical materialism/index/html

4 Battista Mondin, p. 147.

5 Spirkin, A. Dialectical materialism,

6 R.B. Taylor, Elementi di antropologia culturale (Elements of Cultural Anthropology),(Milano: 1972), p. 27.

7 J. Messner, Social Ethics, (London: Herder Books, 1949), p. 149.

8 Adeniran B. Aluko, "Philosophy, Culture and the Quest for Social Order in Africa", in Kolawole A. Owolabi, Issues \& Problems in Philosophy, (Ibadan: Grovacs Network, 2000), p. 45.

9 John S. Mbiti, African Religions and Philosophy, 2nd edition, (Oxford: Heinemann Educational Publishers, 1989), p. 1.

10 Ali A. Mazrui, Cultural Forces in World Politics, (Portsmouth: Heinemann, 1990), p. 7 - 8.

11 Joseph I. Omoregbe, 'African Philosophy: Yesterday and Today' in E. C. Eze (ed.) African Philosophy: An Anthology, (London: Blackwell Publishers), p. 3. 
12 Francis O. C. Njoku, Essays in African Philosophy, Thought \& Theology, (Owerri: Clacom Communications, 2002), p. 4.

13 Samuel Oluchi Imbo, An Introduction to African Philosophy, (Maryland: Rowman \& Littlefield Publishers, Inc. 1998), p. 3 - 4.

14 Abiola Irele, 'In Praise of Alienation' Inaugural Lecture, University of Ibadan, 1982, p. 22.

15 'Philosophy' in The New Illustrated Encyclopedia of Knowledge (1996)

16 O. Reiser, 'World Philosophy and the Integration of Knowledge' in International Logic Review, ed Franco Spisani (1971), p. 18. As quoted by Zubairi, b, Nazeem, African Heritage and Contemporary Life: Experience of Epistemological Change in http:crvp.org/book/series02/11-2/chapter1.htm.

17 Kwame Gyekye, Tradition and Modernity: Philosophical Reflections on the African Experience, (Oxford: OUP, 1997), p. 248.

18 George Will, 'The Primacy of Culture', in the Newsweek Magazine, (Jan.18, 1999), p. 64.

19 For a thematic and systematic account of his liberal philosophy see, J. Locke, Two Treatises of Government, with Introduction by William Carpenter.(especially the Book II) (London: Everyman's Library, 1986),

20 Jim Unah, 'Doing Philosophy and Doing African Philosophy' in Four Decades of African Philosophy Issues and Perspectives, M. E. Asiegbu and J. C. Agbokoba (eds.), (Ibadan: Hope Publications, 2008), p. 40 . 
21 Moses. A. Makinde, African Philosophy: The Demise of a Controversy, (Ile-Ife: Obafemi Awolowo University press, 2007), p. 13.

22 Adeniran B. Aluko, p. 46.

23 Anthony K. Appiah, In My Father's House: Africa in the Philosophy of Culture, (Oxford: OUP, 1992), p. 87.

24 Odera H. Oruka 'Sage Philosophy: The Question of Methodology' in (ed.) Odera Oruka Sage Philosophy,

(Nairobi: African Centre for technology Studies press, 1991), p. 33.

25 Ochieng-Odhiambo, African Philosophy: An Introduction 2nd edition, (Nairobi Consolata Institute of Philosophy Press, 1997), p. 98.

26 Paul J. Hountondji, African Philosophy: Myth and Reality, 2nd edition, (Indianapolis: Indiana University Press, 1996), p. 63.; also see Paul Hountondji 'Reason and Tradition' in (ed.) Odera Oruka and D. A. Masolo, Philosophy and Cultures: Proceedings of the Second Afro-Asian Philosophy Conference

October/Novermber, (Nairobi: Bookwise, 1983), p. 136 - 137.

27 Marcien Towa 'Conditions for the Affirmation of a Modern Philosophical Thought' in (ed.),Tsenay Serequeberham, The Essential Readings, (New York: paragon House, 1991), p. 195.

28 Samuel Oluchi Imbo p. 32.

29 Francis O. C. Njoku, p. 89.

30 Chiek Anta Diop, Precolonial Black Africa: A Comparative Study of the Political and Social Systems of Europe and Black African from antiquity to the 
Formation of Modern States, Trans. Harold Salemon (New Jersey: $\quad$ Africa World Press, 1987), p. ix-xii.

31 'Hermeneutics' in Standard Encyclopedia of Philosophy (online) http:www.stanford.edu

32 For details see, Couzen-Hoy, David. The Critical Circle. (University of California Press, 1981)

33 'Hermeneutics' in Wikipedia, the Free Online Encyclopedia

34 'Hermeneutics' in Standard Encyclopedia of Philosophy.

35 Theophilus Okere, African Philosophy: A HistoricoHermeneutical Investigation of the Conditions of its Possibility, (Lanham: University Press of America, 1983), p. 15.

36 'Paul Ricoeur', in Standard Encyclopedia of Philosophy, http:www.stanford.edu.

37 Theophilus Okere, African Philosophy. p. 16.

38 Paul Ricoeur, Le Conflit des Interpretations, Edution de Seuil Paris (1969), p. 15.

39 Ike Odimegwu, 'Dialogics and Contemporary African Philosophy', in Four Decades of African Philosophy Issues and Perspectives, M. E. Asiegbu and J. C. Agbokoba (eds.), (Ibadan: Hope Publications, 2008), pp. 236 $-237$.

40 Obi Oguejiofor, Philosophy and the African Predicament, (Ibadan: Hope Publications, 2001), p. 118.

41 Okonda Okolo, 'Traditions and Destiny: Horizons of an African Philosophical Hermeneutics' in (ed.) Tsenay Serequeberhan. African Philosophy: The Essential Readings, (New York: Paragon House, 1991), p. 204. 
42 Ibid. p. 206.

43 Martin Heidegger, Being and Time, (Oxford: Basil Blackwell, 1973), p. 27ff.

44 Spirkin, A. Dialectical materialism.

45 For more on the debate between the scientific and humanistic cultures see, F. Barone, The Technological Age, (Milan: Rizozoli, 1974), pp. 28 and 29., Gualberto Grismondi, Critica ed etica nella ragione scientifica, (Critique and Ethics in Scientific Reason),(Turin: Marietti, 1978). 